\title{
A strategy of chemical control of Apera spica-venti L. resistant to sulfonylureas traced on the molecular level
}

\author{
Marta Stankiewicz-Kosyl ${ }^{1 *}$, Mariola Wrochna ${ }^{1}$, Maria Salas ${ }^{2}$, Stanislaw Waldemar Gawronski ${ }^{1}$ \\ ${ }^{1}$ Faculty of Horticulture, Biotechnology and Landscape Architecture, Section of Basic Natural Sciences in Horticulture, Warsaw \\ University of Life Sciences - SGGW, ul. Nowoursynowska 159, 02-776 Warsaw, Poland \\ ${ }^{2}$ DuPont de Nemours (France) S.A.S., 23/25, rue Delarivière-Lefoullon, La Défense 9, F-92800 Puteaux, France
}

Vol. 57, No. 2: 113-119, 2017

DOI: 10.1515/jppr-2017-0015

Received: March 6, 2017

Accepted: April 6, 2017

${ }^{*}$ Corresponding address:

marta_stankiewicz_kosyl@sggw.pl

\begin{abstract}
Three populations of silky bent grass (Apera spica-venti L.) were tested - one that is susceptible and two that are resistant to sulfonylureas. This study assessed the efficacy of control by different herbicides in a pot experiment and estimated the molecular status of resistance to sulfonylureas in analysed populations and its effect on the efficacy of different chemical treatments. The three most effective herbicide rotation schemes were: 1) chlorsulfuron + isoproturon, ethametsulfuron + metazachlor + quinmerac, chlorsulfuron + isoproturon; 2) prosulfocarb + diflufenican, ethametsulfuron + quizalofop-p-ethyl, prosulfocarb + diflufenican; 3) diflufenican + flufenacet, quizalofop-p-ethyl, diflufenican + flufenacet. In most cases it was more difficult to destroy $100 \%$ of the resistant population from Modgarby where the majority of plants had no mutation in the als gene. In the resistant population from Babin there were significantly more individuals with mutation in the als gene, therefore exhibiting target-site resistance.
\end{abstract}

Key words: ALS inhibitors, non-target-site resistance, silky bent grass, target-site resistance, weed control

\section{Introduction}

Silky bent grass (Apera spica-venti L.) is an annual overwintering grass that is considered one of the most important and widespread weeds in winter cereals in central and northern Europe.

Chemical control of this species has often been carried out without sufficient rotation of active substances, which has resulted in the selection of herbicide-resistant biotypes. The first case of silky bent grass resistance to acetolactate synthase (ALS) inhibitors was reported in 2002 by Rola and Marczewska. Currently ALS-resistant biotypes of this species have been found in Austria, Czech Republic, Germany, France, Sweden, Demark and Lithuania (Heap 2017). Unfortunately populations of A. spica-venti resistant to more than one mechanism of action have already been identified. In Poland silky bent grass resistant to ALS and acetylcoenzyme A carboxylase (ACCase) inhibitors has been observed and in Germany a biotype resistant to three sites of action - ALS, ACCase and photosystem-II (PSII) inhibitors - has been identified (Heap 2017). Resistance in A. spica-venti biotypes can also be found against pre-emergence herbicides such as diflufenican and pendimetalin, as well as in populations that are already resistant to ACCase and ALS inhibitors (Petersen et al. 2012).

Resistance to herbicides can be divided into two major types: target-site or non-target-site resistance. So far seven mutation sites in the als gene endowing target-site resistance to ALS inhibitors in different plant species have been reported: Ala122, Pro197, Ala205, Asp376, Arg377, Trp574, Ser653 and Gly654 (Powles and Yu 2010; Massa et al. 2011). Metabolic resistance to ALS inhibitors can be due to increased activity of endogenous cytochrome P450 monooxygenases 
(P450s), glucosyl transferases (GTs) or glutathione S-transferases (GSTs), which can metabolise herbicides (Yu and Powles 2014; Mahmood et al. 2016; Duhoux et al. 2017). This mechanism, potentially conferring resistance to many herbicides, is a particular threat to herbicide sustainability and thus global crop production.

The aim of this study was to determine if herbicide rotations involving active substances other than ALS inhibitors would be more effective on a population of silky bent grass with a predominance of target-site resistance to sulfonureas than on a population with a predominance of non-target-site resistance.

\section{Materials and Methods}

\section{Plant material}

Three populations of $A$. spica-venti were used in the study: a population susceptible to sulfonylureas (S), a resistant population from Babin, Poland (RB) and a resistant population from Modgarby, Poland (RM). Seeds of the susceptible populations originated from Herbiseed. Seeds from resistant populations of silky bent grass came from commercial fields in Poland where cereals had been grown for several years with chemical weed management (including ALS inhibitors) and where unsatisfactory herbicide performance was reported. All seeds were provided by DuPont.

\section{Whole-plant bioassays}

Seeds were sown in pots with compost soil and were well-watered. At the 1-leaf stage seedlings were planted in pots $(100 \times 20 \times 20 \mathrm{~cm})$ with sandy loam soil.
Ten plants from each population were placed in individual pots. The experiment was set up in three replications. From September to November plants were grown in a glasshouse at $15^{\circ} \mathrm{C} / 10^{\circ} \mathrm{C}$ day/night under natural light conditions. From December to the stage of seed collection pots were kept outdoors. Plants were bottom watered if the soil surface was dry except during spring and summer when plants were watered daily to field capacity by drip irrigation. Plants were sprayed at the 2 to 3 -leaf stage. Herbicides were applied with a sprayer equipped with a single nozzle calibrated to deliver $300 \mathrm{l} \cdot \mathrm{ha}^{-1}$ at a spraying pressure of $200 \mathrm{kPa}$. The herbicide treatments applied are presented in Table 1. Treatments for the three consecutive years of the study were chosen according to the crop rotation frequently practiced by farmers, i.e. winter wheat, winter rape, winter wheat.

Herbicide efficacy was assessed 15 and 30 days after treatment and compared with the untreated control. Plants were counted before and after treatment and the A. spica-venti control efficacy is expressed as a percentage of plants that were destroyed by the treatment. Plants that survived were grown to maturity. Pots from the same treatment and population were covered with white polypropylene tissue before flowering to avoid cross-pollination with other treatments and populations. At maturity seeds from each treatment and population were collected and sown back into the same pots from where they had been harvested. In some treatments no seeds were harvested because all the plants had been destroyed by the herbicides. In these cases germination of seeds from the soil bank was simulated: seeds from original populations were sown in small pots with sandy loam soil, kept well-watered and at the 1-leaf stage seedlings were planted in the pots where all the plants had been destroyed by the herbicides.

Table 1. Herbicide treatments applied

\begin{tabular}{|c|c|c|c|c|c|}
\hline \multicolumn{3}{|c|}{ Years 1 and 3} & \multicolumn{3}{|c|}{ Year 2} \\
\hline $\begin{array}{l}\text { Active ingredient } \\
\text { [a.i. }]\end{array}$ & $\begin{array}{l}\text { HRAC } \\
\text { group }\end{array}$ & $\begin{array}{l}\text { Applied doses } \\
{\left[\mathrm{g} \text { a.i. } \cdot \mathrm{ha}^{-1}\right]}\end{array}$ & $\begin{array}{l}\text { Active ingredient } \\
\text { [a.i. }]\end{array}$ & $\begin{array}{l}\text { HRAC } \\
\text { group }\end{array}$ & $\begin{array}{l}\text { Applied doses } \\
{\left[\mathrm{g} \text { a.i. } \cdot \mathrm{ha}^{-1}\right]}\end{array}$ \\
\hline chlorsulfuron & $B$ & 18.75 & ethametsulfuron & $B$ & 18.75 \\
\hline $\begin{array}{l}\text { chlorsulfuron + } \\
\text { diflufenican }\end{array}$ & $\mathrm{B}+\mathrm{F} 1$ & $15+50$ & $\begin{array}{c}\text { ethametsulfuron }+ \\
\text { aminopyralid }+ \text { clopyralid }+ \\
\text { picloram }\end{array}$ & $\mathrm{B}+\mathrm{O}+\mathrm{O}+\mathrm{O}$ & $18.75+12+72+24$ \\
\hline $\begin{array}{l}\text { chlorsulfuron + } \\
\text { prosulfocarb }\end{array}$ & $\mathrm{B}+\mathrm{N}$ & $15+1,600$ & $\begin{array}{l}\text { ethametsulfuron + } \\
\text { metazachlor }\end{array}$ & $\mathrm{B}+\mathrm{K} 3$ & $18.75+750$ \\
\hline $\begin{array}{l}\text { chlorsulfuron + } \\
\text { isoproturon }\end{array}$ & $\mathrm{B}+\mathrm{C} 2$ & $15+1,000$ & $\begin{array}{c}\text { ethametsulfuron + } \\
\text { metazachlor + quinmerac }\end{array}$ & $\mathrm{B}+\mathrm{K} 3+\mathrm{O} / \mathrm{L}$ & $18.75+800+200$ \\
\hline $\begin{array}{l}\text { prosulfocarb + } \\
\text { diflufenican }\end{array}$ & $\mathrm{N}+\mathrm{F} 1$ & $1,600+50$ & $\begin{array}{l}\text { ethametsulfuron + } \\
\text { quizalofop-p-ethyl }\end{array}$ & $B+A$ & $18.75+35$ \\
\hline $\begin{array}{l}\text { diflufenican + } \\
\text { flufenacet }\end{array}$ & $\mathrm{F} 1+\mathrm{K} 3$ & $112+112$ & quizalofop-p-ethyl & A & 35 \\
\hline
\end{tabular}




\section{Molecular analysis of the als gene}

The DNA of three plants from each original population and from each progeny was extracted using the cetyltrimethylammonium bromide (CTAB) method (Doyle and Doyle 1987) with minor modifications. Primer sequences for amplification of domains $\mathrm{A}$ and $\mathrm{B}$ and the area between these domains of the als gene were as described by Krysiak et al. (2011). Genomed S.A. (Warsaw, Poland) was commissioned to undertake purification of the PCR product and sequencing. Chromatograms were analysed using the FinchTV program. The obtained sequences were compared in the ClustalW online-accessed program.

\section{Results}

\section{Whole-plant bioassays}

The efficacy of silky bent grass control in the first year is presented in Figure 1. The most effective treatment was chlorsulfuron + isoproturon. Prosulfocarb + diflufenican and diflufenican + flufenacet were also satisfactorily effective in controlling $A$. spica-venti. Chlorsulfuron, both alone and in a mixture with diflufenican controlled only the S population.

Apera spica-venti control efficacy by herbicides applied in the second year is presented in Figure 2. The most effective mixtures were: ethametsulfuron + metazachlor,

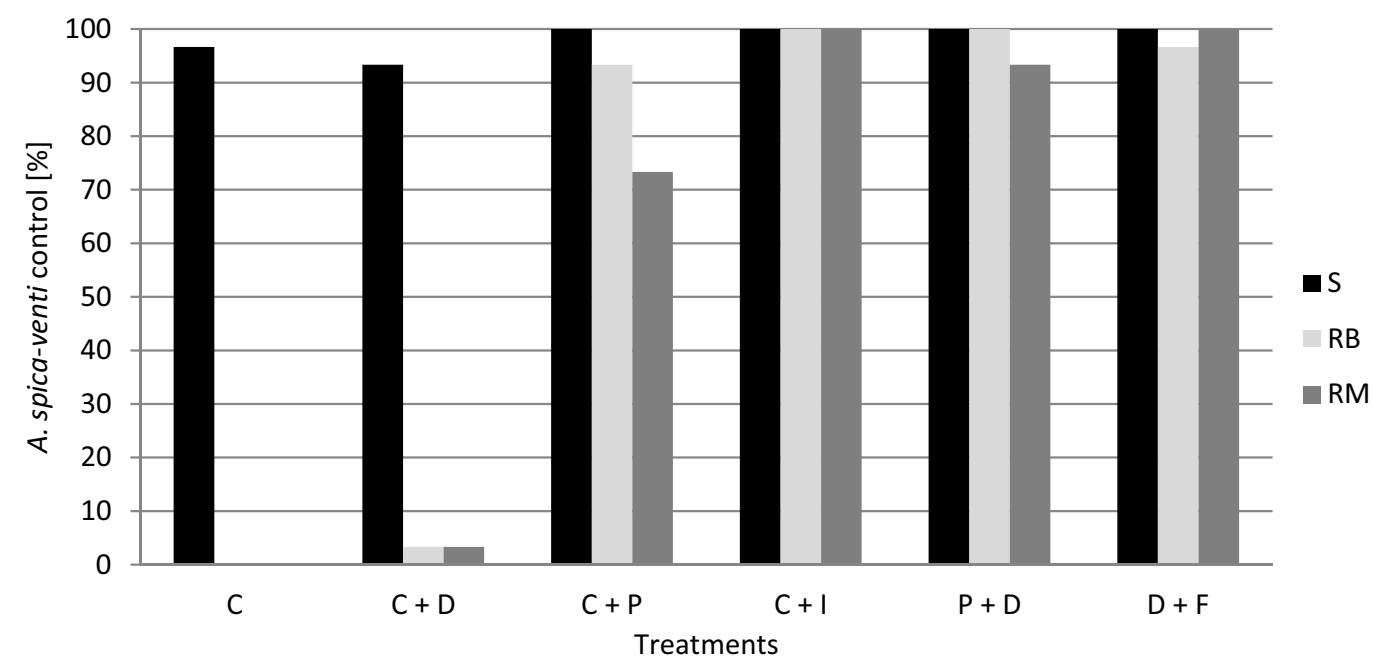

Fig. 1. Efficacy of Apera spica-venti control in the first year assessed 30 days after treatment. $\mathrm{S}$ - population sensitive to sulfonylureas, RB - population resistant to sulfonylureas from Babin, RM - population resistant to sulfonylureas from Modgarby, C - chlorsulfuron, D - diflufenican, P - prosulfocarb, I - isoproturon, F - flufenacet

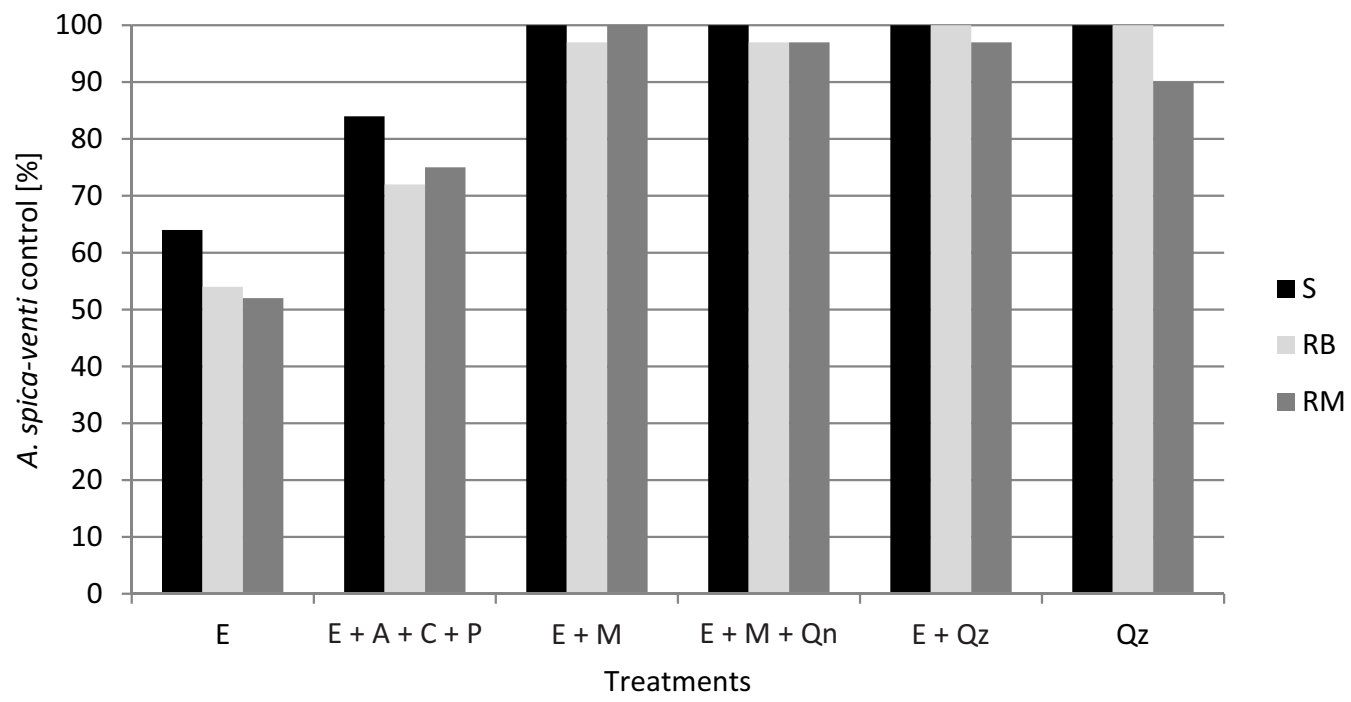

Fig. 2. Efficacy of Apera spica-venti control in the second year assessed 30 days after treatment. S - population sensitive to sulfonylureas, RB - population resistant to sulfonylureas from Babin, RM - population resistant to sulfonylureas from Modgarby, E - ethametsulfuron, A - aminopyralid, C - clopyralid, P - picloram, M - metazachlor, Qn - quinmerac, Qz - quizalofop 


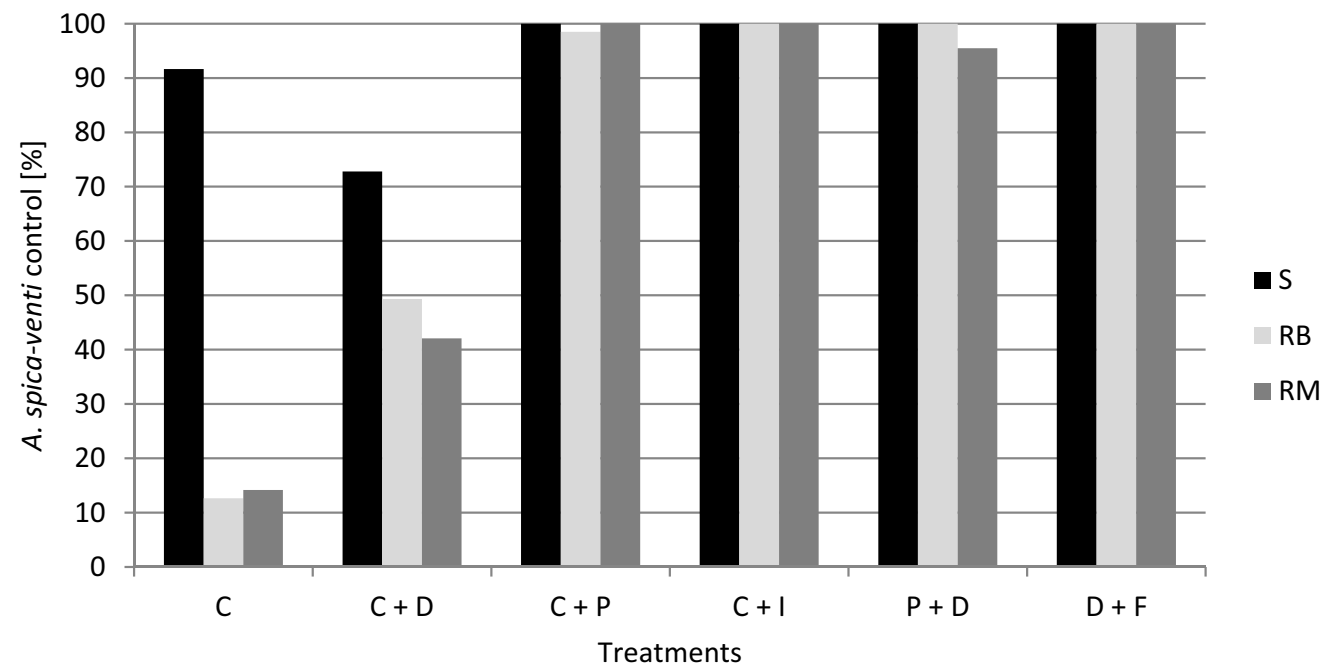

Fig. 3. Efficacy of Apera spica-venti control in the third year assessed 30 days after treatment. S - population sensitive to sulfonylureas, RB - population resistant to sulfonylureas from Babin, RM - population resistant to sulfonylureas from Modgarby, C - chlorsulfuron, D - diflufenican, $\mathrm{P}$ - prosulfocarb, I-isoproturon, F-flufenacet

ethametsulfuron + metazachlor + quinmerac and ethametsulfuron + quizalofop-P-ethyl. Quizalofop-P-ethyl alone was also effective in A. spica-venti control, however $100 \%$ control was obtained for only the $S$ and RB populations. For the RM population, efficacy of control was lower and the surviving plants were large and showed no symptoms of injury or developmental delay. In two of the treatments: ethametsulfuron alone and ethametsulfuron + aminopyralid + clopyralid + picloram - control of the Apera plants was not satisfactory.

Efficacy of silky bent grass control in the third year is presented in Figure 3. The most effective mixtures were: chlorsulfuron + isoproturon and diflufenican + flufenacet where $100 \%$ control was noted. Chlorsulfuron + prosulfocarb and prosulfocarb + diflufenican were also satisfactorily effective in A. spica-venti control. In the treatments of chlorsulfuron alone and chlorsulfuron + diflufenican, the majority of the resistant plants survived.

\section{Molecular analysis of the als gene}

For domains $\mathrm{A}$ and $\mathrm{B}$ of the als gene, the PCR products were approximately 380 and $520 \mathrm{bp}$, respectively. The PCR product of the area between domains A and B was approximately 1,200 bp. Codons 122-205, 367-377 and 574-653 were clearly legible.

Analysis of the als sequence in three plants from each original population did not reveal any mutation endowing resistance in the $S$ population. In the $\mathrm{RB}$ population there were two plants that showed Pro to Thr substitution at position 197 (heterozygotes) and one plant without mutation in the als gene (Table 2). In the RM population after the first year of the study no mutations endowing resistance in domain A were detected. After the second and third years in the RM population one out of three plants analysed had Pro to Thr substitution at position 197 (Table 2). In domain $\mathrm{B}$ and in the area between domains A and B no substitutions at Asp376, Arg377, Trp574, Ser653 or Gly654 codons were detected. In progenies treated with herbicides, in the RB population the majority of plants showed mutations in the codon 197 of domain A. In these plants proline was substituted by threonine. In progenies of the RM population, the situation was different in that the majority of the plants had no resistance-endowing mutations in domains $\mathrm{A}$ and $\mathrm{B}$ or in the intradomain area. Only in progenies treated with chlorsulfuron + diflufenican/ethametsulfuron + aminopyralid + clopyralid + picloram/chlorsulfuron + diflufenican were plants with mutations in domain $\mathrm{A}$ identified. In these individuals proline was substituted by threonine, alanine or serine (Table 2). All substitutions concerned the first position of the 197 codon. The majority of plants with this mutation were heterozygotes at this codon, however some homozygotes were also identified (Table 2).

\section{Discussion}

Active ingredients were chosen in order to evaluate the level of their control of A. spica-venti resistant and susceptible populations in frequent rotations of winter wheat/winter rape/winter wheat. On the basis of the results it can be stated that the most effective herbicide rotation schemes were: 1) chlorsulfuron + isoproturon, ethametsulfuron + metazachlor 


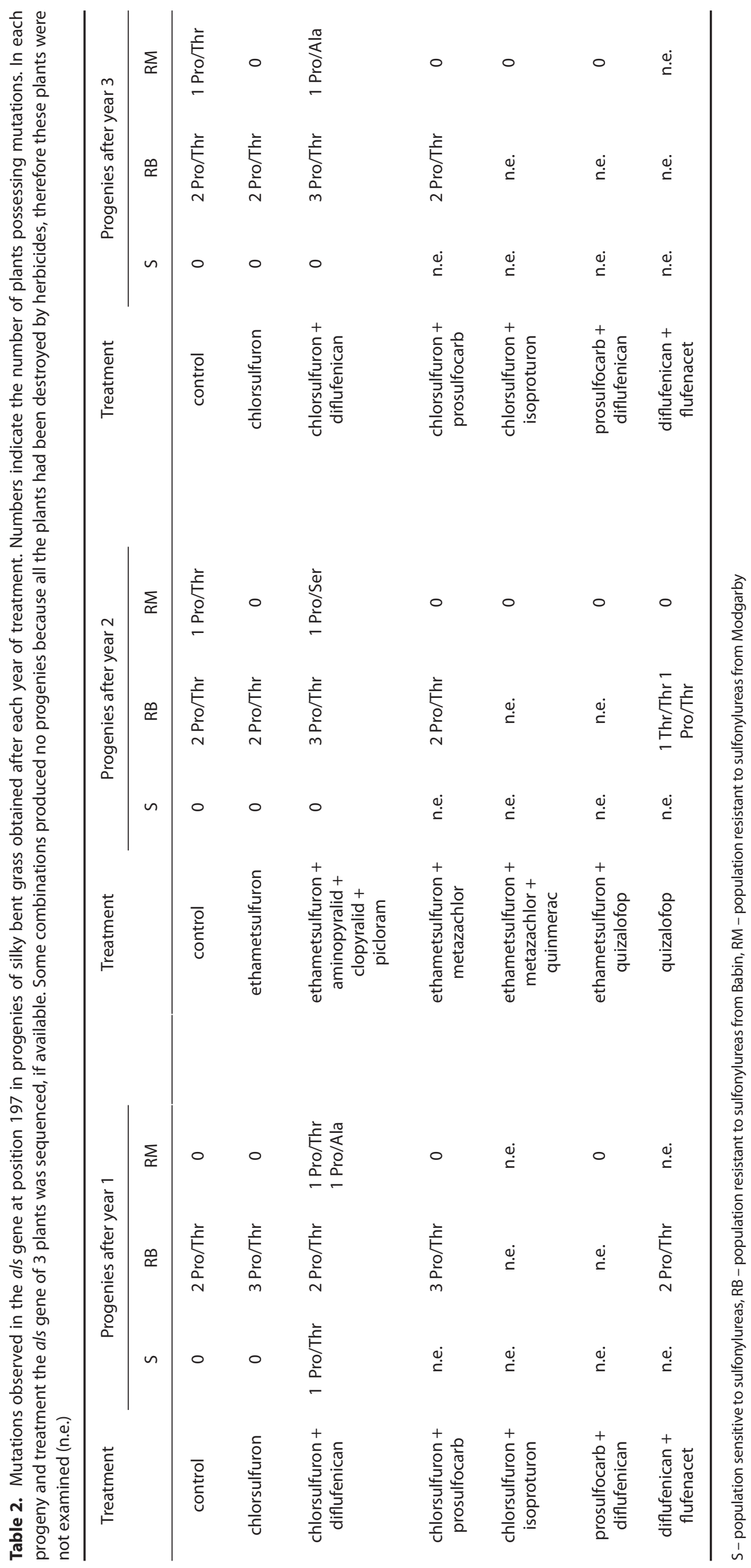


+ quinmerac, chlorsulfuron + isoproturon; 2) prosulfocarb + diflufenican, ethametsulfuron + quizalofop-p-ethyl, prosulfocarb + diflufenican; 3 ) diflufenican + flufenacet, quizalofop-p-ethyl, diflufenican + flufenacet; 4) chlorsulfuron + prosulfocarb, ethametsulfuron + metazachlor, chlorsulfuron + prosulfocarb.

In the second year no herbicide treatment showed $100 \%$ efficacy in Apera control in any of the populations tested. Ethametsulfuron + metazachlor and ethamentsulfuron + quizalofop-p-ethyl proved to be the most efficient $-100 \%$ control of two populations and 97\% control of the third population. The level of control for ethametsulfuron + metazachlor + quinmerac was also high $-100 \%$ for the S population and $97 \%$ for the RB and RM populations. Moreover the plant that survived treatment with ethametsulfuron + metazachlor + quinmerac in the RB population was delayed in its development and produced no seeds. Herbicides with different modes of action are widely recommended as a way of tackling the ALS-resistant phenomenon in weeds. Chemicals from the HRAC group K3 (inhibitors of very long chain fatty acids synthesis) can be an alternative to ALS inhibitors in weed control (Beckie and Tardiff 2012).

In all the plants where mutations were detected, the substitutions concerned codon Pro197. This mutation, which occurs the most frequently, is known to confer resistance to sulfonylureas, with 11 documented amino acid substitutions endowing resistance to ALS-inhibiting herbicides (Powles and Yu 2010; Krysiak et al. 2011; Massa et al. 2011).

The mechanism of ALS resistance in the RB and $\mathrm{RM}$ populations is probably mixed. In the RB population there were significantly more individuals with target-site resistance, however it cannot be excluded that in this population there was a certain level of non-target-site resistance because some individuals without resistance-endowing mutation in the als gene were noted among the survivors. However the RM population seemed to be more diversified. The majority of plants from this population had no mutation in the als gene, but in plants possessing mutation at position 197, three types of substitution were identified (Pro/ Thr, Pro/Ala and Pro/Ser) while in the RB population only the Pro/Thr mutation was detected.

In the RM and RB populations, not all of the tested individuals showed mutations in domains $\mathrm{A}$ or $\mathrm{B}$ or in the intradomain area, although they had survived the herbicide treatment (Stankiewicz-Kosyl et al. 2013). Similar results were obtained by Krysiak et al. (2011) and Hamouzova et al. (2014). The probable cause of this might be the existence of another mechanism of resistance, for example enhanced metabolism. In rigid ryegrass (Lolium rigidum Gaudin) populations in Australia, $70 \%$ of the populations exhibited target-site and non-target-site resistance to ACCase herbicides (Yu et al. 2014). Even in one individual different mechanisms of resistance can coexist (Han et al. 2016). In the same population one to several different mutations can be noted (Yu et al. 2008).

One plant with substitution Pro197 to Thr was detected in the first year in the susceptible population among plants that survived the combination of chlorsulfuron + diflufenican. It is known that herbicides do not generate mutations in plants, but select plants with mutations already existing in a population. Research conducted on L. rigidum populations never previously exposed to ALS inhibitors revealed a high initial frequency of individuals resistant to these herbicides (Preston and Powles 2002). In the herbarium collection of black-grass (Alopecurus myosuroides Huds.), one plant with a mutation conferring ACCase resistance was identified. This specimen was collected in 1888 , thus before any herbicides were on the market (Delye et al. 2013b).

When control efficacy between treatments was compared, it was observed that it was more difficult to destroy $100 \%$ of the RM population. In this population more plants without target-site resistance were identified and it is known from the literature that populations with non-target-site resistance are more difficult to control with the use of different herbicides (Beckie and Tardif 2012; Delye 2013). This suggests that the efficacy of the herbicide treatment depends on the resistance pattern of silky bent grass in the field. Similar results were obtained for black-grass (Rosenhauer et al. 2014).

Few new active ingredients are appearing on the market and therefore mixtures of existing ones can help in prevention and control of weed resistance. However this presents a significant challenge to chemical companies and farmers. Including flufenacet, metazachlor, isoproturon and prosulfocarb in the herbicide rotation schemes can be useful for control of silky bent grass populations resistant to ALS inhibitors. In the same population of silky bent grass individuals with target-site and non-target-site resistance to ALS inhibitors can coexist. Moreover the population with a prevalence of individuals without resistance endowing mutations in the als gene is more difficult to control than the population where most individuals exhibit target-site resistance to ALS inhibitors. Therefore the molecular status of resistant plants can be helpful in identifying the appropriate herbicide treatment.

\section{Acknowledgements}

This study was financially supported by the DuPont Research Project (01/SPPO/2012) granted to M. Stankiewicz-Kosyl. 


\section{References}

Beckie H.J., Tardif F.J. 2012. Herbicide cross resistance in weeds. Crop Protection 35: 15-28. DOI: 10.1016/j.cropro.2011. 12.018

Doyle J.J., Doyle J.L. 1987. A rapid DNA isolation procedure for small quantities of fresh leaf tissue. Phytochemical Bulletin 19 (1): 11-15.

Delye C. 2013. Unravelling the genetic basis of non-target-site-based resistance (NTSR) to herbicides: a major challenge for weed science in the forthcoming decade. Pest Management Science 69 (2): 176-187. DOI: 10.1002/ps.3318

Delye C., Deulvot C., Chauvel B. 2013b. DNA analysis of herbarium specimens of the grass weed Alopecurus myosuroides reveals herbicide resistance pre-dated herbicides. PLoS ONE 8 (10): e75117. DOI: https://doi.org/10.1371/ journal.pone.0075117

Delye C., Jasieniuk M., Le Corre V. 2013a. Deciphering the evolution of herbicide resistance in weeds. Trends in Genetics 29 (11): 649-658. DOI: https://doi.org/10.1016/j.tig.2013.06.001

Duhoux A., Carrere S., Duhoux A., Delye C. 2017. Transcriptional markers enable identification of rye-grass (Lolium sp.) plants with non-target-site-based resistance to herbicides inhibiting acetolactate-synthase. Plant Science 257: 22-36. DOI: https://doi.org/10.1016/j.plantsci.2017.01.009

Hamouzova K., Kosnarova P., Salava J., Soukup J., Hamouz P. 2014. Mechanisms of resistance to acetolactate synthase-inhibiting herbicides in populations of Apera spica-venti from Czech Republic. Pest Management Science 70 (4): 541-548. DOI: https://doi.org/10.1002/ps.3563_

Han H., Yu Q., Owen M., Cawthray G.R., Powles S.B. 2016 Widespread occurrence of both metabolic and target-site herbicide resistance mechanisms in Lolium rigidum populations. Pest Management Science 72 (2): 255-263. DOI: https://doi. org/10.1002/ps.3995

Heap I.M. 2017. International Survey of Herbicide Resistant Weeds. Available on: http://www.weedscience.org. [Accessed: March 2, 2017].

Krysiak M., Gawronski S.W., Adamczewski K., Kierzek R. 2011 Als gene mutations in Apera spica-venti confer broad-range resistance to herbicides. Journal of Plant Protection Research 51 (3): 261-267. DOI: https://doi.org/10.2478/v10045$-011-0043-7$

Mahmood K., Mathiassen S.K., Kristensen M., Kudsk P. 2016. Multiple herbicide resistance in Lolium multiflorum and identification of conserved regulatory elements of herbicide resistance genes. Frontiers in Plant Science 7: 1160. DOI: https://doi.org/10.3389/fpls.2016.01160

Massa D., Krenz B., Gerhards R. 2011. Target-site resistance to ALS-inhibiting herbicides in Apera spica-venti populations is conferred by documented and previously unknown mutations. Weed Research 51 (3): 294-303. DOI: https://doi. org/10.1111/j.1365-3180.2011.00843.x

Petersen J., Naruhn G., Raffel H. 2012. Non target-site resistance inherent in Alopecurus myosuroides and Apera spica-venti - resistance pattern and factors. Julius-Kuhn-Archiv 434: 43-50. DOI: https://www.cabdirect.org/cabdirect/abstract/20123226512

Powles S.B., Yu Q. 2010. Evolution in action: plants resistant to herbicides. Annual Review of Plant Biology 61 (1): 317-347. DOI: https://doi.org/10.1146/annurev-arplant-042809-112119

Preston C., Powles S.B. 2002. Evolution of herbicide resistance in weeds: initial frequency of target site-based resistance to acetolactate synthase-inhibiting herbicides in Lolium rigidum. Heredity 88 (1): 8-13. DOI: https://doi.org/10.1038/ sj.hdy.6800004

Rola H., Marczewska K. 2002. Sulfonylurea herbicide resistant biotype of weeds in Wroclaw Region. Progress in Plant Protection 42: 575-577.

Rosenhauer M., Sievernich B., Petersen J. 2014. Impact of imazamox containing herbicides on the development of resistance in black-grass (Alopecurus myosuroides Huds.). Julius-Kuhn-Archiv 443: 252-260. DOI: 10.5073/jka.2014.443.031

Stankiewicz-Kosyl M., Wrochna M., Nowak P., Popek R., Salas M., Gawronski S.W. 2013. Effect of herbicide combinations on biotypes of wind bentgrass (Apera spica-venti) sensitive and resistant to sulfonureas. Annales COLUMA 2013: 612-617.

Yu Q., Han H., Powles S. 2008. Mutations of the ALS gene endowing resistance to ALS-inhibiting herbicides in Lolium rigidum populations. Pest Management Science 64 (12): 1229-1236. DOI: https://doi.org/10.1002/ps.1624

Yu Q., Han H., Powles S. 2014. Metabolism-based herbicide resistance and cross-resistance in crop weeds: a threat to herbicide sustainability and global crop production. Plant Physiology 166 (3): 1106-1118. DOI: https://doi.org/10.1104/ pp.114.242750

Yu Q., Powles S.B. 2014. Resistance to AHAS inhibitor herbicides: current understanding. Pest Management Science 70 (9): 1340-1350. DOI: https://doi.org/10.1002/ps.3710 